In his brief reply to the ensuing general discussion, Prof. du Plessis said : "If I were in England, I would be an integrationist too, because it is not a danger to English national character, and if $I$ were in America I would be an integrationist too; the negroes in America are in no danger of destroying that great nation of America in its identity. But the Bantus and Indians and Coloureds of South Africa, if they are integrated moro fully than they are now, would undoubtedly destroy our great South African nation".

The general discussion, in which Prof. J. L. Montrose, Prof. A. J. Ayer, Mr. L. Behrons and others took part, was largely concerned with what steps could be taken to assist the South African univer- sities and the non-European students. Mr. T. D. Smith outlined what was being done in Oxford by the Joint Action Committee against Racial Intolerance, now a university society with more than two thousand undergraduate members, which is raising a fund to provide a scholarship for a non-white from South Africa. Dr. H. J. Grenville-Wells, who was brought up in South Africa and attended for five years a South African university, deplored the fact that she had had to come to England and go to America to meet Africans of university standard, and to find out what Africans and other coloured people want for themselves. At a meeting where plain speaking was not spared, this seemed to some the most telling indictment of apartheid.

\title{
THE CHEMICAL SOCIETY OF FRANCE, I857-1957
}

$\mathrm{T}$ HE centenary of the Société Chimique de France was celebrated in the Sorbonne on July 16, the President of the Republic, the Minister of Education, and the Secretaries of State for Agriculture and Public Health being present. An address was given by the president of the Society, Prof. R. Delaby, who reviewed the history of the foundation and development of the senior association of French chemists. It was foundod on June 4, 1857, on the initiative of three young chemists, Arnaudon, Collinet and Ubaldini, who, with a few other young colleagues, decided to meet weekly for the purpose of keeping in touch with all branches of the science by reading memoirs, extracts, and abstracts of work published in French and foreign journals. At that time the younger chemists of France included Wurtz, Sainte-Claire Deville, Pasteur and Berthelot. Durnas was president in 1859, Wurtz being secretary and Pasteur and Cahours vice-presidents. In 1864, the publications of the Society were united under the title of Bulletin de la Société chimique de Paris; in the same year a decreo of Napoleon recognized the Society as of public utility. By the creation of the Bulletin the Society acquired a growing influence, the enthusiasm of Wurtz being especially influential, so that he was regarded as the true founder of the Society.

When the Society was founded, the chemists of France were divided into three rival schools. That of Sainte-Claire Deville at the École Normale Supérieure continued the older traditions of Berthollet and Gay-Lussac, who were mainly interested in physical chemistry, and it continued to use the dualistic notation of Berzelius. In the Ecole de Pharmacie, Berthelot used the equivalent formulæ (as he did for long after Cannizzaro's atomic weights were accepted by other chemists). In tho École de Médecine, Wurtz was a protagonist of the new school, based on the atomic thoory, and with his collaborators, including Friedel, Ladenburg, Salet, Crafts, Grimaux, and Beilstein, used structural formulæ and the idea of chemical bonds. On account of Wurtz's influence, the new Society became the centre of interest in atomistic ideas in France. Delaby quotes what was said by Gautier on the occasion when the Society had reached its fiftieth year, to the effect that in passing from one school to another in the earlier times, a young chemist had to learn to speak a different chemical language as well as to make profound adjustments in his outlook on chemical theory.

In 1884, it was proposed that the name of the Society should be changed to Société Chimique de France, but authorization for this was not given by the Council of State until 1906, the statutes being amended accordingly. Among past presidents were three permanent secretaries of the Académie des Sciences, Dumas, Pasteur, and Berthelot, and three recipients of a Nobel Prize, Moissan, Grignard, and Sabatier. Delaby in his lecture gave brief accounts of the careers of several presidents of the Society. Dumas is best known for his discovery of substitution and homology; he was the author of a large "Traité de Chimie appliquées aux arts" and the famous "Lecons de philosophie chimique". Pasteur, a great experimenter, founded stereochemistry, and later in his researches in the fields of biochemistry and biology made important contributions to medicine. Berthelot contributed to the fields of organic synthesis, thermochemistry, the physical chemistry of the detonation wave, and the chemistry of agriculture, as well as to the history of Greek alchemy and the alchemy of the Middle Ages by the publication of texts. He also occupied important positions in the Statesenator, Minister of Public Instruction, and Foreign Secretary. Moissan worked mainly in the field of inorganic chemistry; he discovered fluorine and invented the electric furnace, with which he studied the carbides, borides and silicides of metals. Grignard is well known as the discoverer of the organomagnesium compounds and of their applications in organic synthesis. Sabatier was a pupil of Berthelot and was associated with him in many researches, but is best remembered for his process of catalytic hydrogena. tion, partly worked out with Senderens. Later notable names are Moureu, Urbain, Delepine, Matignon, and Jolibois, whose work was briefly reviewed.

Prof. Delaby's lecture gave an interesting survoy of the development of chemistry in France from about 1850 to the present day. It shows how the Société Chimique de France participated in this and how the most famous members of the Society advanced the various branches of the science. It is a record of which the French nation is justifiably proud.

J. R. Partington 